\title{
The effect of sucrose concentration in the culture medium on the formation of abscisic acid and the activity of the photosynthetic apparatus of grape plants in vitro \\ Sundyreva M.A., Rebrov A.N., Mishko A.E., Lutsky E.O.
}

${ }^{1}$ FSBSI NCRRIH\&V, Krasnodar, Russia; ${ }^{2}$ FSBSI RRIV\&W named after Ya.I. Potapenko branch of the FGBNU «FRANZ», Novocherkassk, Russia

E-mail:taurim2012@yandex.ru

Key message. An increase in sucrose in the medium increased the content of pigments, gene expression of the photosynthetic apparatus, growth processes, and H2O2, but decreased the quantum yield of photosynthesis. With a change in the sucrose content in the medium, the expression of $A B A 1$ increased most intensively. $30 \mathrm{~g} / \mathrm{l}$ of sucrose in the medium inhibited the expression of genes involved in the formation of $A B A$.

Keywords: grapes, pre-adaptation, composition of the culture medium, photosynthesis, abscisic acid

The difficulty of transferring plants from in vitro to non-sterile conditions is associated with the development of water and oxidative stress, a low level of photosynthetic processes, and a poorly developed root system. This requires the selection of in vitro conditions that promote pre-adaptation. The study of the physiological mechanism of plant preadaptation will allow more efficient production of planting material, reduce plant losses during acclimatization.

The aim of the study was to determine the effect of the concentration of sucrose in the culture medium on the synthesis of abscisic acid and the activity of the photosynthetic apparatus of grape in vitro plants.

The content of pigments, malondialdehyde (MDA), hydrogen peroxide was determined by spectrophotometric methods. Assessment of gene expression was carried out by real-time PCR. Evaluation of the effectiveness of photochemical photosynthesis reactions was carried out using PAM fluorimetry.

High concentrations of sucrose in the medium provoked an increase in the content of photosynthetic pigments, while at the same time they led to a decrease in the quantum yield of photosynthesis and the ratio of chlorophyll A and chlorophyll B. The expression of the genes of the photosynthetic apparatus increased with an increase in the concentration of sucrose in the medium. An increase in the content of $\mathrm{H}_{2} \mathrm{O}_{2}$ in microplants occurred with an increase in the sucrose content in the culture medium. The maximum $\mathrm{H}_{2} \mathrm{O}_{2}$ content was observed at at 20 and $30 \mathrm{~g} / \mathrm{l}$ sucrose. The expression of genes involved in the formation of $\mathrm{ABA}$ increased with increasing sucrose concentration to $20 \mathrm{~g} / \mathrm{l}$. Inhibition of the expression of these genes was detected at a concentration of $30 \mathrm{~g} / \mathrm{l}$ sucrose in the culture medium. The expression of the ABA1 gene (zeaxanthin epoxidase) changed mainly with a change in the composition of the medium. An increase in the concentration of sucrose in the culture medium led to an increase in the expression of a number of photosynthetic genes and genes involved in the synthesis of ABA, $\mathrm{H}_{2} \mathrm{O}_{2}$. A more efficient functioning of the photosynthetic apparatus was revealed at a low concentration of sucrose in the medium. The reported study was funded by RFBR and Ministry of Education and Science of the Krasnodar Territory, project number 19-44-230037 r-a.

\section{Влияние концентрации сахарозы в культуральной среде на образование абсцизовой кислоты и активность фотосинтетического аппарата растений винограда in vitro Сундырева М.А., Ребров А.Н., Мишко А.Е., Луикий Е.О. ${ }^{1}$ ФББНУ СКФНЦСВВ, Краснодар, Россия; \\ ${ }^{2}$ ФГБНУ ВНИИВиВ им. Я.И. Потапенко филиал ФГБНУ «ФРАНЦ», Новочеркасск, Россия}

\begin{abstract}
Аннотация. Увеличение сахарозы в среде повышало содержание пигментов, экспрессию генов фотосинтетического аппарата, ростовых процессов, $\mathrm{H}_{2} \mathrm{O}_{2}$, но снижало квантовый выход фотосинтеза. При изменении содержания сахарозы в среде наиболее интенсивно повышалась экспрессия АВАІ. Сахароза 30 г/л в среде ингибировала экспрессию генов, участвующих в образовании $A Б K$.

Ключевые слова: виноград, предадаптачия, состав культуральной среды, фотосинтез, абсцизовая кислота

Сложность перевода растений из условий in vitro в нестерильные условия связана с развитием водного и окислительного стресса, низким уровнем фотосинтетических процессов, слабо развитой корневой системой, что требует подбора условий «в пробирке», способствующих предадаптации. Исследование физиологического механизма предадаптации растений in vitro к условиям ex vitro позволит более эффективно производить посадочный материал, снизить потери растений в процессе акклиматизации.

Цель - определить влияние концентрации сахарозы в культуральной среде на синтез абсцизовой кислоты и активность фотосинтетического аппарата растений винограда in vitro.

Методы. Содержание пигментов, малонового диальдигеда (МДА), перекиси водорода определяли спектрофотометрическими методами. Оценка экспрессии генов проводилась методом ПЦР в реальном времени. Оценка эффективности фотохимических реакций фотосинтеза - методом РАМ-флуориметрии.

Высокие концентрации сахарозы в среде провоцировали повышение содержания фотосинтетических пигментов, в то же время приводили к снижению квантового выхода фотосинтеза и соотношения хлорофилла А и хлорофилла Б. Экспрессия генов фотосинтетического аппарата увеличивалась при повышении концентрации сахарозы в среде. Повышение содержания $\mathrm{H}_{2} \mathrm{O}_{2}$ в тканях микрорастений происходило параллельно увеличению содержания сахарозы в культуральной среде. Максимальное содержание $\mathrm{H}_{2} \mathrm{O}_{2}$ было отмечено в вариантах опыта 20 и 30 г/л сахарозы. Экспрессия генов, участвующих в образовании АБК, возрастала при повышении концентрации сахарозы до 20 г/л. При концентрации сахарозы в культуральной среде 30 г/л было выявлено полное ингибирование экспрессии данных генов. При изменении состава среды главным образом менялась экспрессия гена ABA1 - зеаксантин эпоксидазы, преобразующей зеаксантин в виолоксантин. Повышение концентрации сахарозы в культуральной среде приводило к повышению экспрессии ряда фотосинтетических генов и генов, участвующих в синтезе АБК, $\mathrm{H}_{2} \mathrm{O}_{2}$, в то же время более эффективное функционирование фотосинтетического аппарата выявлено при низкой концентрации сахарозы в среде. Исследование выполнено при финансовой поддержке РФФИ и Министерства образования и науки Краснодарского края в рамках научного проекта № 19-44-230037 p-a.
\end{abstract}

